\title{
THE ROLE OF TECHNOLOGY IN EFL CLASSROOM
}

\author{
Fahri Haswani \\ Universitas Negeri Medan \\ fahrihaswani@yahoo.com
}

\begin{abstract}
In response to an appeal from Indonesia's Ministry of Education and Culture to all universities and colleges to improve the quality of tertiary education toward regional and international standard, language institutions are making great efforts to further promote the foreign language learning process. In the last few years there have been dramatic changes in the ways that languages are taught by communicative approach and the introduction of technological tools. In recent years, the use of technological aids, especially those related to computers, has increasingly become a common feature of the classroom. There is no doubt that computer based instruction will occupy a more central role in the foreign language classroom in the future. Information technology has drawn the interest of teachers of English as a second or foreign language in non-English speaking countries. The technology integration into the curriculum is not a single concept which is generated from one single theory nor does it give full guidelines for the implementation in practical situation. This issue constitutes ideas from many different theories. This paper discusses the issue of technology contributions in EFL classroom. The question raised in this paper is how technology facilitates the attainment of course goals. The answer of the question will help English teachers to clarify the real problems of the initiative so that the innovation and possible changes can be aligned with the need of the students. However, this literature review only covers limited issues related with the role of technology in EFL classroom. Further discussion from other different points of view is still needed to create more complete description of conceptual foundation of the innovation.
\end{abstract}

Key Words : Technology, EFL, classroom

\section{ABSTRAK}

Lembaga- lembaga bahasa secara serus menerus mempromosikan peningkatan kualitas pengajaran bahasa sebagai respon terhadap keputusan Kementerian Pendidikan dan Kebudayaan. Beberapa tahun belakangan ini telah terjadi perubahan yang cukup drastis dalam pengajaran bahasa dalam menggunakan pendekatan komunikatif dan teknologi di kelas. Penggunaan teknologi, khususnya yang berkaitan dengan komputer telah banyak digunakan di sekolah-sekolah, sehingga di masa yang akan datang teknologi akan memainkan peranan yang sangat penting dalam pengajaran bahasa asing. Teknologi informasi telah menarik minat guru bahasa Inggris diberbagai negara yang bahasa pertamanya bukan bahasa Inggris. Pengintegrasian teknologi kedalam kurikulum bukan berasal dari konsep tunggal yang diambil melalui satu teori dan tidak memberikan petunjuk yang jelas untuk pelaksanaannya di kelas. Oleh karena itu, paper ini mencoba menjawab pertanyaan bagaimana teknologi berperan dalam meraih tujuan dari pengajaran bahasa Inggris. Pembahasan pada artikel ini diharapkan membantu guru bahasa Inggris untuk mengatasi masalah terkait penggunaan teknologi yang disesuaikan dengan kebutuhan siswa. Namun kajian dalam artkel ini hanya terbatas pada hal-hal yang berkaitan dengan peranan teknologi (ICT) dalam pengajaran bahasa Inggris di kelas, untuk itu diperlukan pembahasan yang lebih mendalam yang meliputi deskripsi terhadap dasar pemikiran pada inovasi pengajaran bahasa.

Kata Kunci: Teknologi, pembelajar bahasa Inggris sebagai bahasa asing (EFL), kelas 


\section{INTRODUCTION}

Nowadays, Information and Communication Technology (ICT) have developed vastly. In this globalization era, the use of ICT in education is rapidly expanding in many countries, and is now seen worldwide as both necessity and opportunity. They develop due to challenges that are faced by human beings all this time. There are always situations where people are encouraged to think, produce and be creative to particular condition (Mutansyir, 2013). This vast development provides challenges and opportunities to aspects of life including education. In educational field, especially in English teaching and learning, the advancement of the use of ICT provides a strong demand to bring into reality its applications in classroom teaching. The use of ICT for communicating with those not physically present in the classroom can add a new dimension to literacy work. ICT opens new possibilities for young writers, enriches the curricular emphasis on genres and forms, and expands children's horizons by encouraging them to write in new ways for new audiences.

\section{In learning English students} should know four languages skills and components. Writing is one of the four language skills. It is very important for students to be able to write in English for their future life. To learn to write, students can start with informal writing, for example, writing in a diary. ICT can be used as an effective medium to accommodate this.

One of the ways that can be applied to enhance in a multi learning environment using ICT systems, particularly in the teaching of writing, is the use of blog (a short term for weblog). A blog is a frequently updated website that often resembles an online journal. Having a blog is having online diary where students can write anything they are interested in, edit and publish as often as they would like to, and share their writing with others. In addition, writing in blogs provides a real audience for students' writing. Usually, teacher is the only person who reads students' writing. With blog, students can find themselves writing for real audiences apart from their teacher, e.g. their peers, students from other classes, or even other countries, their parents, and potentially anyone with the internet. This will encourage them to produce better and effective piece of writing.

\section{INFORMATION AND COMMUNI- CATION TECHNOLOGY (ICT)}

Since its vast development, ICT has become a very important 
component, which is now seen as both a necessity and an opportunity. Even UNESCO, stated in the Dakar Framework for Action in April 2000, has identified the use of ICT as one of the main strategies for achieving the EFA (Education for All) goals (UNESCO-Ck.htm, 2005). The simultaneous impact of globalization, the spread of English and technological development have transformed learning and teaching English as a lingua franca in an unprecedented way (Warschauer and Healey, 1988). As a result, both English and ICT have become essential literacy skills for a growing number of non-native speakers of English to ensure full participation in the information society (Jung, 2006). The use of ICT in and for education is expanding rapidly in many countries.

In addition, Merchant (2003) states that the use of ICT can add a new dimension to literacy work when applied in the classroom teaching and learning. It may open new possibilities for young writers, enriching the curricular emphasis on genres and forms, and expanding children's horizons by encouraging them to write in new ways for new audiences. In relation to the use of ICT in teaching, Zhu and Kaplan (2001) propose a model for teaching with technology that can be viewed in Figure 1.
The figure explains that from a system approach, teaching with technology involves four major components, namely the students, the instructor, course content, and technology tools.

Figure 1. A Model of Teaching with Technology

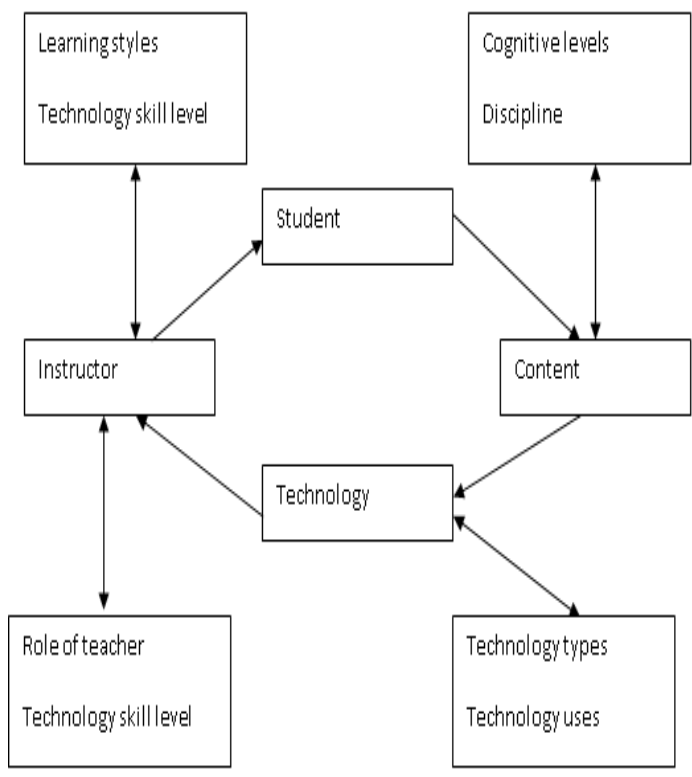

An examination of each component raises a set of issues that the teachers need to consider in order to make technology integrations successful. For example, content can be examined in terms of learning outcomes and the discipline being taught. Teachers can think of their own experience with technology by having their amount of time for planning. They also can expose an access to technology as well as their preferred learning styles. Finally, they can turn to the 
technology itself and analyze it according to its functions. This approach to teaching and learning with technology assumes that the four components are integrated and that changes in one part will require adjustments to the other three in order to achieve the same goals ( $\mathrm{Zhu} \&$ Kaplan, 2001).

The importance and the significance of ICT are believed to be able to help students learn better. Pelgrum (1996) further states that ICT:

- encourages pupils to collaborate with one another and take responsibility for their own learning;

- helps to nurture individual talent, independence and a strong sense of self worth and a strong sense of self worth and confidence;

- encourages pupils to use their imaginations and promotes creativity; and

- develops inquiry and communication skills and creates appropriate contexts for critical thinking, decision making, and problem solving activities.

In the teaching of English, ICT can be integrated with the four skills namely speaking, listening, reading, and writing as well as other language components. It enhances interactive teaching and learning styles. It also extends pupils ability to work independently and make connections between their work in English and in other subjects. For the students, Pelgrum (1996) states that ICT can help them to:

- use a wide range of strategies to explore contrast, comparisons and connections dynamically;

- annotate text in innovative ways,

- enrich or broaden the context of literary study;

- see texts in alternative versions;

- use a wide range of analytical and critical techniques;

- sort and process text and data quickly and efficiently;

- order and arrange text and data experimentally, using combinations of word, image sound and hypertext;

- save, record, edit and adapt their work quickly and efficiently;

- retain evidence of the editing process so that it can be examined;

- change the organizational structure and qualities of texts to suit different audiences and purposes;

- compose multi-authored texts;

- select from a wider range of audiences, throughout the world; and;

- exercise choice of medium and design while composing. 
Many schools recognize the power of ICT to promote learning, both in improving their current practice, and responding to developing awareness as to how, and at what pace pupils learn, and the skill they need for effective learning. There is an increasing evidence that by increasing the pace of learning and motivation among pupils and teachers, the use of ICT also contributes to raise standards of achievement (Jager \& Lokman, 1999). Additionally, writing with a computer and making use of ICT can increase the amount of writing that students could perform, the extent to which students can edit their writing. Because of that, students can write and express their experiences and thoughts freely and creatively.

\section{THE ROLE OF TECHNOLOGY IN EFL CLASSROOM}

Computer technology is identified to have the power of generating effective learning activities in a second or a foreign language. The development of computer networking results in an expansion of the range of computer mediated communication to help students participate in the negotiation of meanings (Kern \& Warschauer, 2008). This is relevant to the needs of interaction as the basic requirement of second and foreign language learning. Most writers on educational technology argue that computer technology in English language learning has created environments for promoting student participation, as well as generating authentic contexts for interaction and the negotiation of meaning.

The computer technology has given facilities to ESL/EFL teachers to present individualized instructions. CALL (computer assisted language learning) has been utilized for presenting self-contained, programmed applications such as tutorials, drills, simulations, instructional games, test practice and so on. Some ESL/EFL teachers have also tried to use such general applications as word processors and presentation programs.

In the present situation, network based language learning has also gained important attention (Kern \& Warschauer, 2008). Network based language learning involves the use of computers connected to one another in either local or global networks.

Recent articles and studies focus on the value of using computermediated communication as a tool for facilitating foreign language learning. Lai and Zhao (2006) examined the relationship between noticing and textbased synchronous discussion. They claim that computer mediated communication increases the rate at 
which students notice their own linguistic mistakes and generates explicit forms of negotiation of meaning. Moreover, computermediated instruction has been identified to promote dialogic interaction (communication strategies in chat). Kim and Rissel (2008) report that instructors' belief about language teaching, instructors' role and the interaction role in computer-based foreign language teaching influence the instructional process. In addition, Marshall (2007) shows that engagement model of computer integrationist effective in the design, implementation, and outcomes of the website associated with the course.

\section{ENGAGEMENT IN FOREIGN LANG- UAGE LEARNING}

Learning engagement has become a crucial element in foreign language learning. Generally speaking, students develop their language competence through engaging in communicative activities in ESL/EFL classes. Kearsley and Shneiderman (1998) introduced a concept regarding learning engagement in computerbased instruction, Engagement Theory. They claim that Engagement Theory has similar features with constructivist and problem-based learning approaches. They believe that technology can facilitate engagement in way which are difficult to achieve otherwise (Kearsley and Shneiderman, 1998). However, technology does not in itself bring about improvement in learning. Although it may bring positive impacts on students' motivation, the improvement of learning will depend on how the technology is utilized in the real application of learning experiences.

Engagement theory emphasizes meaningful learning so that it is very consistent with constructivist approaches which assume that "individuals are actively involved right from birth in constructing personal meaning that is their own personal understanding, from their experience (William and Burden, 1997). Moreover, Engagement Theory emphasizes collaboration among peers and a community of learners. It can be aligned with situated learning theories. Learning collaboratively with others has been suggested by theories in sociocognitivism which emphasizes that the involvement of other people in learner's life significantly influences his mental development (Vygotsky, 1978). Other people help learners to enhance learning by selecting and shaping the learning experiences presented to them.

The basic principle of engagement theory is related with the collaborative learning model. 
Engagement Theory comprises three components:

1. Relating: learning activities that occur in a group context.

2. Creating: learning activities that are project-based.

3. Donating: learning activities that have an outside (authentic) focus.

In relation with this, collaborative work encourages students to clarify and verbalize their problem, thereby facilitating solutions (Kearsley and Shneiderman, 1998). Creating involves student participation in the development of their assessment tasks: students have to define the project and focus their efforts on application of ideas to a specific context (Kearsley and Shneiderman, ibid). Donating stresses the value of making a useful contribution while learning (Kearsley and Shneiderman, 1998), a feature that motivates learners because they are engaged with an activity they value.

Some studies have used the framework provided by the Engagement Theory and give critical contribution on the application of this theory in EFL instruction. Marshal (2007) used a case study in which Website is used in an academic writing course. The study analyzed how effective Engagement Theory has been in the design, implementation and outcomes of the website associated with the course. Marshal claims that Engagement Theory was deemed relevant and useful to the aim of providing an authentic experience of the writing process. Reich and Daccord (2009) used the modification of Engagement Theory in a case study to investigate how the Collect-RelateCreate-Donate (CRDR) framework shaped the development of the "Day in the life of a teenage Hobo Project". The project used Engagement Theory to describe whether the Personal Response System (PRS) was effective for engaging students in acquiring the knowledge and skills needed to conduct research.

\section{COMMUNICATIVE APPROACH TO LANGUAGE TEACHING}

The use of Engagement Theory as the basic concept of computer integration into the EFL curriculum is relevant with the implementation of communicative language teaching principles. Communicative language teaching emphasizes on student engagement with authentic, meaningful, contextualized discourse and achievement in the second language. William and Burden (1997) argue that "individuals acquire a foreign language through the process of interacting, negotiating and conveying meanings in the language in purposeful situations" (William and Burden: 1997, p. 168). They continue to claim that 
students' learning engagement in language learning activities will have positive impacts on the increase of second and foreign language competencies. In addition, language learners' engagement in meaningful, motivated communication activity using the target language is considered the best route to becoming both literate and fluent in that language (Stevick, 1980; Brown, 1994). Since 1980s cognitively oriented perspectives on language acquisition has gained popularity. Dell Hymes, an American sociolinguist, and Michael Halliday, a British linguist, argue that language is not just a private, "in the head" affair, but rather a socially constructed phenomenon." There are rules of use without which the rules of grammar would be useless" (Hymes, 1971, p . 10). Hymes continues to claim that syntax and language forms were best understood not as autonomous, a contextual structures. Consequently, they should be used as meaning resources in particular conventional ways in particular speech communities.

In the practice of communicative language teaching, meaningful interaction has been the central element in second language pedagogy. Studies in second language teaching fields show that it is insufficient for the teacher to teach only linguistic competence. They claim that the teaching and learning process should include sociolinguistic competence, discourse competence, and strategic competence (Canale, 1983; Canale and Swain, 1980). Furthermore, communicative processes become as important as linguistic product, and instruction become more learnercentered and less structurally driven. Therefore, interaction in the process of language learning is put as the central position in ESL/EFL learning context.

\section{THE DESIGN OF COMPUTER IN EFL CLASSROOM}

The design of computer integration in language classroom will determine the effectiveness of the computer technology in the language classroom to provide language learning environment. Kern and Warchauer (2000) argue that the computer does not in and of itself bring about the improvement of learning so that the effective integration of computer technology depends upon how the computer technology is used in order to encourage students to engage in learning. Research indicates that teachers have the most impact for technology use in schools. The teachers become the central actor to determine the instruction that takes place inside the classroom. Research studies on the computer use in the classroom indicate that teachers' perception, belief and 
philosophies become crucial factors in creating constructive classroom practice using computer technology. Gorder (2008) argues that computer integration is more about the teacher's effective use of technology that makes a difference in reforming the school. The teacher becomes the crucial person to transform the way they teach in the traditional classroom in order to generate the improvement of student learning. Therefore, the teacher's technology integration decisions will determine the effective nature of classroom environment that facilitates students to engagement in meaningful learning processes.

In foreign language classroom, teacher can develop some strategies in teaching integrated language skills such as watching conversation video from YouTube, applying writing electronic letter by using email, answering questions on line, and giving comments in social media. These learning activities are based on Dryden and Vos (1994) that electronics now provides the tools to communicate instantly with almost any person on earth. The first nation to fully realize that power and link it with new learning techniques could lead the world in education.

Teacher can ask students to watch their favorite video in YouTube. This activity can motivate students to browse some videos which give model how to speak English naturally and how to pronounce words like a native speaker. After watching the video, students can be instructed to practice or tell what they watch. Before watching activity is begun, teacher must explain that they have to watch educational video.

For students in senior high school, teacher can create writing activity by email. Students have to send a letter to their teachers or their friends by email. Before this activity is conducted, teacher should prepare students by explaining theory and strategy how to write a letter in email. This activity encourages students to be more creative in using computer.

Answering question on line also should be applied in the classroom as one of variations in giving test. This strategy can be applied in two alternative ways. Teacher can design a new program or use an already existing program in the internet. If teachers have programming skill, they can design a program which contains some interesting quizzes and tests. This strategy will not only motivate students to learn language but also will inspire students to be more creative in using computer. The problem is the number of teachers with programming skill is very little but it does not mean online test cannot be conducted. Teachers can use some learning quiz software in 
internet. They just need to browse and download the materials for students.

Nowadays is social media era. Teachers also can use social media such as Facebook and twitter to learn language. Teachers can write his or her writing on Facebook or twitter to get their students' comments. Best comment will be discussed again in classroom and this interaction will build nice experience for students in learning foreign language.

\section{CONCLUSION AND SUGGESTION}

Language learning engagement becomes very crucial in computerbased language learning. Computer technology have the capacity to facilitate people to access to other people as well as to information and data (Kern \& Warchauher, 2000) so that it can serve as medium for local and global communication and provide accesses to authentic materials. Moreover, computer interactions are also potential to enhance communication skill to strengthen language through computer support group interactions (Bourdon, 1999). Instructors or curriculum developers in EFL need to be consistent with the use of communicative language teaching to develop effective integration of computer technology into the curriculum. Engagement model for developing EFL curriculum design gives an effective framework for designing learning activities. In other words, communicative language teaching principles and engagement model of learning may serve as a guide for designing effective technology integration into language teaching. The two pillars will ensure that the foreign language lesson will give students opportunities to explore and interact in meaningful learning experience, and the language learning activities will consists of collaborative, creative, and purposeful experiences.

\section{REFERENCES}

Bitner, N., \& Bitner, J. (2002). Integrating technology into the classroom : Eight keys to success. Journals of Technology and Teacher Education,10, 95100.

Bourdon (1999). Principles and Practice in Technology. Pergamon, Oxford.

Brown, H. (1994). Principles of language learning and teaching. Englewood Cliff, NJ: Prentince Hall Regents.

Canale, M. (1983). From communicative competence to communicative language pedagogy. Language and communication. In J. C. Richard \& R. W. Schmidt 
(Eds.). Language and communication. New York: Longman.

Canale, M., \& Swain, M. (1980). Theoretical bases of communicative approaches to second language teaching and testing. Applied Linguistics, 1(1), $1-47$.

Dryden and Vos (1994). The Learning Revolution, Rolling Hills estates, California, USA.

Gorder, L. M. (2008). A study of teacher perceptions of instructional technology integration in the classroom. Delta Pi Epsilon Journal, 50(2), 63-76. http://hd 1.handle.net/1903/3885.

Hymes, D. (1971). General Introduction. In Hymes, D. Language in Culture and Society: xxi-xxxii. Harper and Row, New York.

Instructional Journal of Education and Development, Inc: http://home.spry.net.com /glearsley/engage.htm.

Jager and Lokman (1999). Impacts of ICT in Education. The ole of the Teacher and Teacher training, Paper Presented at the European Conference in Educational Research, Lahti, Finland 22- 25 September 1999.
Jung, Sei Hwa (2006). The Use of ICT in Learning English as an International Language. http:// Education.uci.edu/Person/wars hauer-in/docs/networksed.pdf.

Kearsley, G and Shneiderman, B (1998). Engagement Theory. Retriewed 2012, from Instructional Journal of Education and Development ,Inc: http://home. spry.net.com/glearsley/engage. htm.

Kern, R., Ware, P., \& Warschauer, M. (2008).

Network-based language teaching Encyclopedia of language and education (pp. 1374-1385): Springer.

Kim, H. K., \& Rissel, D. (2008). Instructors' integration of computer technology: Examining the role of interaction. Foreign Language Annals, 41(1), 61-80.

Lai, C., \& Zhao, Y. (2006). Noticing and text-based chat. Language Learning \& Technology, 10(3), 102-120.

Marshall (2007). Engagement Theory, Web CT, and Academic Writing in Australia. International Journal of Education and Development Using Information and Communication Technology (IJEDICT), 3 (2), 109 - 115. 
Merchant, G. (2003). E-mail me your thoughts: digital communication and narrative writing. Reading, 37(3), 104-110. doi: 10.1046/j.00340472.2003.037030 03.

Pelgrum and Plomp (1997). New Approaches for Teaching, Learning and Using Information and Communication Technologies in Education. Prospect; volume XXVII, no.3. September 1997, Springer. Netherland.

Reich and Daccord (2011). Best Ideas for Teaching with Technology. M.E. Sharpe Inc. New York.

Stevick, E. (1980). Teaching languages: A way and ways. Rowley, MA: Newbury House.

Vygotsky (1978). Interaction Betweeen Learning and Development. www.psy.com.edu-siegler/vy gotsky78.pdf.
Warschauer and Healey (2012). Technology in Language Learning 2012. Wilis and Webquest, www.fcsh.unl.pt/docentes/ cceia/ images/stories/pdf/tefl /Carolyn.pdf.

Warschauer, M., \& Kern, R. G. (2000). Network-based language teaching: Concepts and practice: Cambridge university press.

William and Burden (2009). Motivation in Second and Foreign Language Learning and Development. www.psy.cmu.edu-siegler/vy gotsky78.pdf.

Zhu and Kaplan (2001). A Model for Teaching with Technology. www.crltumich.edu/inst/mod el. 